\title{
Smart Transportation: Modeling Barriers of Electric Vehicles Charging Infrastructure
}

\author{
Ruchita \\ Bharti School of Telecommunication Technology and Management, Indian Institute \\ of Technology, New Delhi, India \\ ruchitahoney91@gmail.com
}

\begin{abstract}
It is to identify the potential barriers for Electric Vehicles Charging Infrastructure (EVsCI) for Smart transportation management in India, to model the barriers, to obtain the hidden constructs of identified barriers, to validate a four-level transition management framework, and to understand the interrelationships among these barriers. After identifying 20 barriers, Exploratory Factor Analysis (EFA) has been employed to get hidden constructs and categorize them in four-level transition management framework. Then, a seven-level hierarchical Total Interpretive Structural Modeling (TISM) based model has been proposed for finding inter-relationships among the barriers and to understand the driving power and dependency among barriers. The hierarchical framework has been developed using TISM which reveals the inter-relationships among barriers. This research work classifies barriers into four quadrants using Matriced' Impacts Croises Multiplication Applique' and Classment (MICMAC). This research highlights the necessity of using EVs in public transportation and the need of minimizing drawbacks in the way of adopting Electric Vehicles (EVs). This study will help policy makers to pay proper attention to frame policies to encourage manufacturing and adoption of EVs and to overcome drawbacks in the path of adopting EVs suitable for the developing countries.
\end{abstract}

Keywords: EVsCI, Stakeholder theory, Transition management theory, EFA, TISM, MICMAC. 


\section{Introduction}

Smart Transportation is a universal need which may be considered as combined outcome of technology as well as management techniques. To make transportation systems more efficient \& reliable, Intelligent Transportation System (ITS) has been applied abroad with modern technology in multimodal transportation. The role of the efficient \& reliable transportation system in the economic \& social advancement of the nation is undeniable. Transport sectors share an important and major role in the economic development of country. This sector is responsible for major energy usage (Ratanavaraha and Jomnonkwao, 2015). The expansion and modernization of transportation system is important for ensuring the growth of nations' economy. At the same time, there is a need to overcome the drawbacks in adopting smart and modernized transportation system. EVs have replaced the public transportation system abroad in developed as well as in some developing countries. The traditional transportation system has some important drawbacks regarding larger $\mathrm{CO}_{2}$ emission due to having internal combustion engine vehicles. The transportation sector emits $\mathrm{CO}_{2}$ in very large quantity nearby about 23\% (IEA, 2015). Petroleum-waste transportation system is mainly responsible for environmental problems across the world. To curtail the pollution, the only feasible and cheap alternative to petroleum vehicles is electric-based transportation. EVs are the need for transportation in order to minimize $\mathrm{CO}_{2}$ emission (Ehsani et al., 2010). Due to $\mathrm{CO}_{2}$ emission, global temperature rises and private cars contribute substantially to such emission (Allen et al., 2009; Matthews et al., 2009; Meinshausen et al., 2009; Nicholas Stern, 2006).

EVs may be a suitable alternative which are not dependent on traditional fuel which are responsible for increasing $\mathrm{CO}_{2}$ emissions and other environmental issues. The public transportation system contributes a large portion of traditional gases in the environment and it has an adverse effect on humans as well as Nature. The negative effect of the changed transportation system should be checked. Government intensive investment and policies are supposed to encourage the adoption of EVs though it is not enough for replacing the present transportation system rapidly in developing countries.

The prime concern in the path of adopting EVs is to improve the EVsCI. There are several challenges that include high maintenance cost, insufficient electric power supply, lack of proper government support, poor battery quality, poor consumer perception \& knowledge, low revenue generation, etc. EVs may become the most suitable alternative to traditional transportation systems using fossil fuels. It can reduce air pollution and improve the climate in long run. The challenges associated with installing a new charging station may be considered as barriers in the way of adopting EVs. The challenges/barriers in installing charging stations have been identified in this paper.

The importance of electric vehicles and smart transportation systems has been highlighted in this study. Developing countries are playing a great role in 
encouraging industries to manufacture EVs suitable for their market \& their citizen. This study attempts identify important barriers and to minimize those to make a more smart and reliable public transportation system. Policymakers and owners of industries should pay attention to these adverse effects of the transportation system and develop a system to minimize these concerns.

Considering the drawbacks of the present transportation system and research gap, the research objectives are listed below: -

1.To identify barriers of electric vehicles charging infrastructure.

2.To determine a lesser set of hidden constructs for these barriers \& validation of transition management frame.

3.To develop model of barriers and obtaining inter-relationships among them.

4.To analyze barriers considering their driving power and dependence.

Applying stakeholder theory, transition management concept, doing a literature survey, and conducting interviews with industry representatives, policymakers of government, and academicians, the first objective is achieved. By employing EFA on identified barriers, the hidden construct of these barriers has been derived and four-level transition management framework has been validated and the second objective is achieved. A hierarchy-based model for identified barriers is obtained by employing TISM methodology and the third objective is achieved. At last MICMAC technique is employed to find out driving power and dependency among barriers and fourth objective is achieved. Rest portions of this paper are organized in the following way: Section II- Literature review, Section III- Research structure and techniques employed, Section IV- Results and analysis, Section V- Discussion and Implications, Section VI- Comparison of EFA and TISM Results, Section VIIConclusions and Scope of Future Work.

\section{Literature Review}

It has been done in 2 sections. The first part deals with the stakeholder theory and the concept of transition management and its significance. The next part presents a review of the concerned literature.

A. Stakeholder Theory

The stakeholder perspective is a novel way to create value and trade between companies and people. Harrison, Freeman, and Zyglidopoulos discuss the foundation concepts and implementation of stakeholder management as well as the advantages of this approach which provides to firms and their managers. They present several tools which may be helpful for managers in implementing the stakeholders' thinking and creating value with and for them. The element concludes by discussing how managers can create stakeholder-oriented control systems and by examining some of the important stakeholder-related issues that are worthy of future scholarly and managerial attention. A stakeholder has been defined by Freeman as "any group or individual who can affect or is affected by the 
achievement of organizations' objectives". The stakeholder theory focuses on the link between business and all people who have a stake in it, namely customers, employees, suppliers, investors, and the community (Kannan, 2018). The main objective of stakeholder theory is to protect the interests of stakeholders. So, this theory gives the concept that each stakeholder is important and responsible for the success of a system. The interests of all stakeholders should go in the same direction. This theory has universal recognition and is being utilized by different research scholars (Yuen et al., 2017).

There is limited research work in the area of electric vehicle charging infrastructures involving stakeholder theory. To our knowledge, no previous research has applied stakeholder theory for EVsCI analysis. This study has interaction with different stakeholders such as government, technology providers, transportation sector, users, academicians, different organizations who were helpful in identifying a total 20 barriers (Table 1) which are responsible in the way of adopting EVs. This theory is proper and suitable in this research work since it incorporates different stakeholders' views.

B. The Concept of Transition Management

Transition management is an official government policy/approach which facilitates and accelerates sustainability transitions. It should have vision, learning and experimenting. It comprises of viewpoints of many persons and different approaches.

Key principles to transit in management as a form of governance: -

- It seeks the participation of masses rather than some persons to include views of common people and their beliefs.

- It should have long - term thinking (at least 25 years) having many visions including short-term objectives.

- It focuses on learning at the lowest level also and gives the concept of "learning by doing, doing by learning".

- Objectives should be flexible and adjustable at the system level.

It is a concept/approach to handle complicated issues. Some scientists have applied 3 levels of operational structure for transition management such as strategic, tactical, and operational (Kemp et al., 2007; Loorbach et al., 2008). But we have developed another fourth level known as performance level for this research work. These four levels are defined as follows: -

1) Strategic level barriers

The barriers coming in this category have a high impact on decisions taken by management and these barriers have a long-term impact on decisions and policies framed by concerned authorities. This study reveals that due to the lack of proper encouraging industrial policies \& government support, it has an adverse effect on adopting EVs in public. Several other barriers have been identified in this category through the literature review \& opinions from experts of industries and 
academicians of related fields.

2) Tactical level barriers

The barriers falling in this category are considered for resource allocation \& performance assessment against goals. Lack of space of EV charging \& lack of charging stations are two important tactical level barriers for EVsCI.

3) Operational level barriers

The barriers of this category have an influence on decisions taken by low-level management such as daily maintenance cost and operational decisions. The high cost of charging infrastructure $\&$ installation and high maintenance costs are the key barriers in this category.

4) Performance level barriers

It is the outcome of this study. The non-availability of EVs' right model for the suitable requirement and low revenue generation are barriers in the path of adopting EVs. These barriers are considered at this level.

C. Smart Transportation System

In this section, an attempt has been made to review the previous work and methodologies related to intelligent transportation systems or smart transportation. The recently published research articles related to supply chain management, transportation, EVs, and their charging infrastructure are undertaken in this study. The supply chain is the most important tool for smart transportation management in developed as well as in developing countries. Supply chain management can be done in several areas such as purchasing, manufacturing, and transportation, etc. It has been discussed, analyzed, and focused on the impact of smart cities initiative and big data on supply chain management and specifically investigated the connections between smart cities, big data, and network characteristics (Tachizawa et al., 2015).Many researchers suggested a novel modeling and simulation method to address the dynamic risk effects on Chemical Supply Chain Transportation (CSCT) system considering the time-dependent system behaviour in different operating conditions ( $\mathrm{Li}$ et al., 2016).The researchers have reviewed Integrated Transportation Inventory (ITI) models for various supply chain configurations and the research gap has been established (Mosca et al., 2019). Transportation is a very important issue for a human being to go from one place to another and to send their goods to the destination. Some of the researchers paid attention to the opportunities and challenges of the applications related to transportation such as route-planning, car-parking, traffic safety, and pricing information, etc. (Siuhi and Mwakalonge, 2016). An ITS having advanced technologies of electronics, communication, computer control, sensing, and detection in the transportation system is used to improve at par with the developed countries. Scientists have presented the effective use of ITS and other traffic data and developed a link-level and time-based dynamic vehicle emission inventory (Din et al., 2019; Zhang et al., 2018). The possibilities of vehicle-to-vehicle and vehicle-to-infrastructure communication modeling and 
computer simulations have been discussed and presented by some of the researchers (Petrov et al., 2017).In smart transportation, different forms of transportation are integrated into a single passenger to arrange a complete door-to-door journey. Several countries are providing this type of facility to passengers. It has been investigated by some researchers how the smart cities context has transformed transportation systems into smart mobility with three characteristics people-centric, data-driven, and powered by bottom-up innovation (Chen et al., 2017). One researcher refers to the application of information and communication technologies to road transport, infrastructure, vehicles, and users to improve safety, increase productivity, and ensure a greener environment (Sadiku et al., 2017). Attempts have been made by some researchers regarding deep learning models in multiple transportation systems (Wang et al., 2018). EVs are considered an important transportation system to reduce dependency on petroleum products and $\mathrm{CO}_{2}$ emissions. EVs may be useful in solving some other problems also related to the environmental (Bradley and Frank, 2009; Bubeck et al., 2016; Prud' homme and Koning, 2012; Tran et al., 2013).EVs are becoming an alternative to traditional fossil fuel vehicles. Production and selling of EVs are increasing worldwide. EVs are economical and having environmental benefits by substituting electricity in place of petroleum products with respect to traditional engine vehicles such as internal combustion engine vehicles (ICEVs) (Larson et al., 2014). These EVs have reduced $\mathrm{CO}_{2}$ and greenhouse gases as well as enhanced energy security. These EVs also encourage to use non-conventional energy sources (Egbue and Long, 2012). Considering the advantages of EVs and improvement in atmosphere features, most of the countries are involved in making their policies to increase production and making people aware to adopt EVs (Zheng et al., 2012).Charging infrastructure is an important parameter for EVs. Lack of good charging infrastructure and space for charging stations are prime drawbacks in the way of adoption of EVs in an urban area also (Lane and Potter, 2007; Potoglou and Kanaroglou, 2007; Nocera and Cavallaro, 2016). The manufacturing cost of EVs has become very high due to the special type of batteries also (Browne et al., 2012; Brownstone et al., 2000). The battery required for EVs should have a large battery capacity which raises the driving range and initial expenditure (Krause et al., 2013; Sierzchula et al., 2014; Bubeck et al., 2016). EVs are driven by electric motors which should have less maintenance cost (Krause et al., 2013).Some researchers have empirically analyzed and identified the relationship between experience satisfaction via exhibition experience and purchase desire (Seung-Wan Ju et al., 2020). This research has proved that there is a need to improve corporations' image, pay attention to customers' need and make them aware regarding the product. An empirical study on the social marketing of companies in India has established the direction of the social marketing of companies in developing countries/India (Jinyoung Shin et al., 2020). They analyzed the social marketing practices of companies working in India. From 
literature reviews and expert opinions, 20 barriers have been identified which are listed in Table 1.

Table 1: Barriers of EVsCI

\begin{tabular}{|c|c|c|c|}
\hline & Barriers & Descriptions & References \\
\hline B1 & $\begin{array}{l}\text { High Cost of charging } \\
\text { infrastructure \& } \\
\text { installation }\end{array}$ & $\begin{array}{l}\text { Advanced charging infrastructure \& } \\
\text { installation accessories are costly. }\end{array}$ & $\begin{array}{l}\text { (Lopez-Behar et } \\
\text { al., 2019) }\end{array}$ \\
\hline B2 & $\begin{array}{c}\text { Cost of building system } \\
\text { upgrades }\end{array}$ & $\begin{array}{l}\text { Due to charging infrastructure installation in } \\
\text { Multi-Unit Residential Buildings (MURS) }\end{array}$ & $\begin{array}{l}\text { (Lopez-Behar et } \\
\text { al., 2019) }\end{array}$ \\
\hline B3 & High Battery cost & $\begin{array}{l}\text { A new battery is to be replaced at the end of } \\
\text { the previous battery life. }\end{array}$ & (She et al., 2017) \\
\hline B4 & High Maintenance cost & $\begin{array}{l}\text { Charging stations require high maintenance } \\
\text { costs due to the modernized system. }\end{array}$ & $\begin{array}{l}\text { (Pradip Kumar } \\
\text { Sarkar and Jain, } \\
\text { 2018; She et al., } \\
\text { 2017) }\end{array}$ \\
\hline B5 & $\begin{array}{l}\text { Low Revenue } \\
\text { generated/profit }\end{array}$ & $\begin{array}{l}\text { Due to the non-availability of right/good } \\
\text { EVs and poor knowledge regarding these, } \\
\text { Revenue generation is not up to mark. }\end{array}$ & Expert opinion \\
\hline B6 & Poor Battery life & The lifetime of battery degradation & $\begin{array}{l}\text { (Graham-Rowe } \\
\text { et al., 2012; } \\
\text { O'Neill et al., } \\
\text { 2019; She et al., } \\
\text { 2017) }\end{array}$ \\
\hline B7 & $\begin{array}{l}\text { Slow substantial } \\
\text { Technical Progress on } \\
\text { Battery Performance }\end{array}$ & It is undesirable for plug-ins. & $\begin{array}{l}\text { (O’Neill et al., } \\
\text { 2019) }\end{array}$ \\
\hline $\mathrm{B} 8$ & $\begin{array}{l}\text { Lack of space for EV } \\
\text { charging }\end{array}$ & $\begin{array}{l}\text { In many urban areas, there is not so much } \\
\text { space available for EV charging. }\end{array}$ & $\begin{array}{l}\text { Expert Opinion } \\
\& \text { (Pradip Kumar } \\
\text { Sarkar and Jain, } \\
\text { 2018) }\end{array}$ \\
\hline B9 & $\begin{array}{l}\text { Poor consumer } \\
\text { perceptions \& } \\
\text { knowledge }\end{array}$ & Due to lack of awareness & $\begin{array}{l}\text { (Rezvani et al., } \\
\text { 2015) }\end{array}$ \\
\hline B10 & $\begin{array}{l}\text { Non-availability of } \\
\text { right /good EV } \\
\text { car/scooter model }\end{array}$ & $\begin{array}{l}\text { Due to not providing proper economical } \\
\text { support from the government and not having } \\
\text { perception and knowledge to the public. }\end{array}$ & Expert Opinion \\
\hline B11 & $\begin{array}{l}\text { Limited driving range } \\
\text { (Range anxiety) }\end{array}$ & $\begin{array}{c}\text { EVs require frequent charging due to limited } \\
\text { driving range. }\end{array}$ & $\begin{array}{l}\text { (Dua et al., 2019; } \\
\text { O’Neill et al., }\end{array}$ \\
\hline
\end{tabular}




\begin{tabular}{|c|c|c|c|}
\hline & & & $\begin{array}{l}\text { 2019; She et al., } \\
\text { 2017) \& Expert } \\
\text { Opinion }\end{array}$ \\
\hline B12 & $\begin{array}{l}\text { Insufficient electric } \\
\text { power supply }\end{array}$ & $\begin{array}{l}\text { The non-availability of the uninterrupted } \\
\text { power supply may have an adverse effect on } \\
\text { the performance of EVs. }\end{array}$ & $\begin{array}{l}\text { (Pradip Kumar } \\
\text { Sarkar and Jain, } \\
\text { 2018) } \\
\end{array}$ \\
\hline B13 & $\begin{array}{c}\text { Lengthy Charging time } \\
\text { after driving EVs for } \\
\text { seven days. } \\
\end{array}$ & $\begin{array}{l}\text { Charging becomes more difficult and } \\
\text { charging time increases }\end{array}$ & (She et al., 2017) \\
\hline B14 & $\begin{array}{c}\text { Lack of charging } \\
\text { stations }\end{array}$ & $\begin{array}{c}\text { Due to the lack of proper space and high cost } \\
\text { of charging infrastructure. }\end{array}$ & $\begin{array}{c}\text { (Robinson et al., } \\
\text { 2014) }\end{array}$ \\
\hline B15 & $\begin{array}{c}\text { Poor Charging } \\
\text { infrastructure/condition } \\
\text { at home, at the } \\
\text { workplace and on- } \\
\text { highway service } \\
\text { stations }\end{array}$ & $\begin{array}{l}\text { Charging conditions in the workplace } \\
\text { including office buildings, in-residence } \\
\text { communities, and highway service stations is } \\
\text { not proper. }\end{array}$ & (She et al., 2017) \\
\hline B16 & $\begin{array}{c}\text { Lack of proper } \\
\text { government support }\end{array}$ & $\begin{array}{c}\text { Due to the slow formation of rules and } \\
\text { regulations for encouraging industries to } \\
\text { produce good EVs. }\end{array}$ & $\begin{array}{l}\text { (Steinhilber et } \\
\text { al., 2013) \& } \\
\text { Expert Opinion } \\
\end{array}$ \\
\hline B17 & $\begin{array}{l}\text { Non-availability of } \\
\text { battery swap facility }\end{array}$ & $\begin{array}{c}\text { Batteries available for EVs have no facility } \\
\text { for swapping so they may be treated as } \\
\text { barriers. }\end{array}$ & $\begin{array}{c}\text { (Grote et al., } \\
\text { 2019; Noel et al., } \\
\text { 2019) }\end{array}$ \\
\hline B18 & Impact of a local grid & It has an adverse effect on the local grid. & $\begin{array}{l}\text { (Noel et al., } \\
2019)\end{array}$ \\
\hline B19 & Safety & $\begin{array}{l}\text { Safety is a great concern for researchers as } \\
\text { traffic is growing rapidly. }\end{array}$ & $\begin{array}{l}\text { (Pradip Kumar } \\
\text { Sarkar and Jain, } \\
\text { 2018; She et al., } \\
\text { 2017) }\end{array}$ \\
\hline B20 & Concern of Reliability & $\begin{array}{l}\text { Several studies have considered reliability as } \\
\text { an important concern in the way of adoption } \\
\text { of EVs due to the poor performance of EVs. }\end{array}$ & $\begin{array}{l}\text { (Noel et al., } \\
\text { 2019) }\end{array}$ \\
\hline
\end{tabular}

\section{Research structure and techniques employed}

The methodological approach has been discussed for analyzing and modeling the barriers of $\mathrm{EVsCI}$ for the transformation of traditional vehicles to $\mathrm{EVs}$ for adding decarbonization and eco-friendly features. The process is explained as follows: -

A. Research framework

The particular objectives to achieve in this research work have been shown in Fig 1.

B. To identify the potential barrier 
In this research work, 20 barriers of $\mathrm{EVsCI}$ have been identified (Table 1) with the help of transition management theory, stakeholder theory, a literature survey, experts' opinions, and arranging interviews with industrialists and academicians of that field. In this way, the first objective is achieved.

C. Methodology

Two techniques/methodologies named EFA and TISM have been employed to achieve our defined objectives.

EFA has been employed to analyze 20 identified barriers to get hidden constructs and categorize them in a four-level framework such as strategic, tactical, operational, and performance level. After that employing TISM, an inter-relationship of driving power and dependence among barriers has been obtained. A literature survey shows that no study has been done regarding Electric Vehicles Charging Infrastructure using EFA \& TISM methodology.

a)EFA

EFA is a methodology applied to reduce the identified barriers forming a lesser group of the hidden constructs (Fabrigar et al., 1999). Another important purpose of EFA is to give inter-relationships among measured items and hidden constructs (Hair et al., 2010). The measured items are so arranged that the items reflect the same hidden construct. The sample size should be greater than 100 and the subjectsto-elements proportion of 4:1/5:1 is suitable for performing as suggested (Floyd and Widaman, 1995; Hair et al., 2010). In this research, 20 measured variables have been taken out of a sample size of 205. Some factors have been extracted which have eigenvalue more than 1 and these are kept for further testing (Tabachnick and Fidell, 2007).

- Questionnaire Formation

A set of questionnaires was formed for getting opinions from experts of the related field of charging infrastructure of EVs \& to overcome its potential barriers for increasing the utilization of EVs in transportation systems. Initially, potential barriers regarding the Charging Infrastructure of Electric Vehicles were selected \& listed from the literature survey. A pilot study was also completed by 11 experts ( 6 from industry, 3 from academicians, 2 from government officials). On the basis of suggestions/opinions obtained from experts in the pilot study, a few amendments /modifications/changes were made to the questionnaire, and then it was finalized.

- Data collection.

The prepared survey questions set were managed to 410 delegates of industry, top rank officials, and academicians related to the field of EVs. The survey questions were sent by e-mail. Reminders and calls were also made to some persons. After doing such efforts, 307 feedbacks were obtained. However, only 205 feedbacks were full in all respects. And these completed responses were applied for further investigation. The feedback rate of $38 \%$ may be identified in the survey. The response of experts showed that there were $40 \%$ female and $60 \%$ male among 
experts, $18 \%$ between the age group of $20-30$ years, $45 \%$ between the age group of $30-40$ years, $22 \%$ between the age group of 40-50 years, and the rest were above 50 years of age. It also shows that out of the total considered responses, $23 \%$ of responses have experience between 1-5 years, $45 \%$ of having an experience below 10 years, $20 \%$ of having an experience less than 25 years \& rest were higher than 25 years of involvement in the EVs area. From 205 responses, 10 were from PSUs, 115 from private sector industries, 5 from government \& other organizations, and 75 from academics.

b)TISM

A qualitative technique named TISM is used for analyzing inter-relationship among the statistically significant barriers. TISM (Sushil, 2012) is a novel extension of Interpretive Structural Modeling (ISM) in which ISM makes the answer of

"What" and "How" of research work (Warfield, 1974) whereas TISM gives a reply of "Why" also. In an ISM model, a directed graph, as well as interpretation, can be made at two levels knowns as links and nodes. Clarification for nodes and links is accomplished by representing the respective elements expressing it and restrained to the contextual exchange between elements and direction of their exchange in a pair-wise comparison respectively (Lee et al., 2010).

"Interpretive matrix" is prepared as a managerial tool to answer "Why" which is not answered by ISM. The interpretive matrix is to resolve the drawback of ISM as a managerial tool for structural modeling. It gives a matrix for the interpretation relationship for pair-wise variables which may be in the form of binary or fuzzy (Rajput and Singh, 2019). So, integrating ISM with an interpretive matrix, TISM methodology is developed. TISM methodology (Dubey et al., 2017; Jena et al., 2016; Sushil, 2012) is a modified methodology of ISM which can be treated as a novel extension of overcoming drawbacks of ISM methodology (Jharkharia and Shankar, 2004; Mandal and Deshmukh, 1994; Singh et al., 2003; Warfield, 1974; Watson, 1978). 


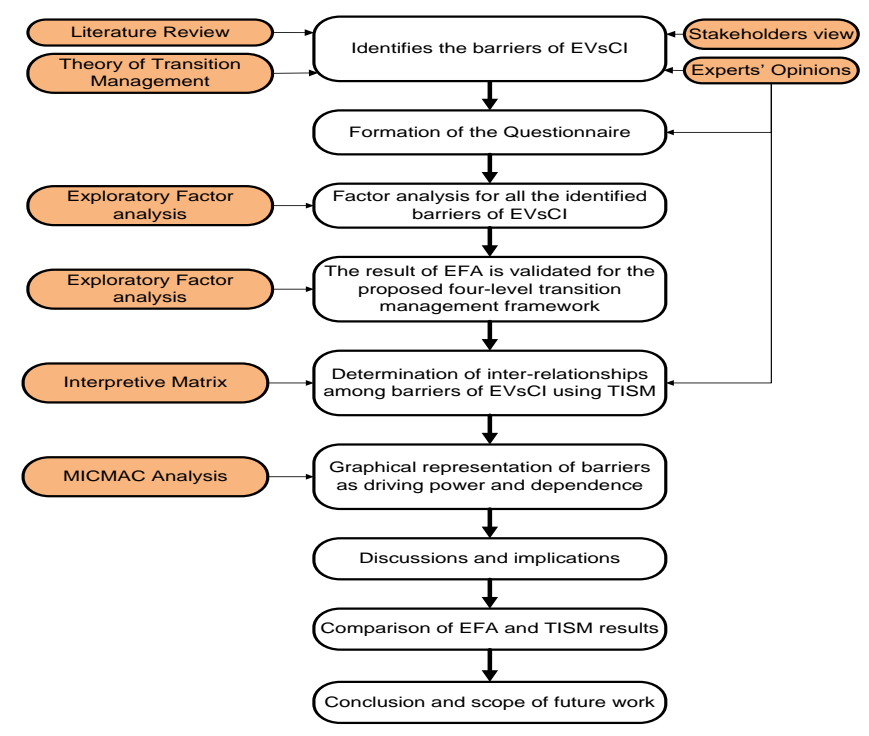

Fig. 1: Research framework

Some drawbacks of ISM methodology responsible for developing TISM methodology are listed below (Sushil, 2012): -

Drawbacks of ISM Methodology: -

- Only individuals can utilize this methodology.

- Computer facilities are essential for implementation and getting benefits from ISM.

- The same interpretation of the models for different individuals cannot be provided by this technique.

- Answers to what and how of research are provided by it but doesn't answer to why.

- It is unable to examine transitive correlation in the diagram.

Since the analysis for direct linkages is not so strong in the case of ISM methodology, it may not be able to take the entire decision rightly for processing. By utilizing the side of the link joining 2 elements, relations are interpreted in a graphical model. Consequently, the ISM approach is modified to form a TISMbased model. It provides interpretation for nodes and links which are not available in ISM. Modified ISM known as TISM is established to take decisions also and has been utilized for research purposes.

Characteristics of TISM: -

- It is a modified technique of ISM.

- It is helpful in presenting even complicated systems in a simple way.

- It overcomes almost all demerits of ISM.

- Analysis of links as well as nodes is provided in an architectural model.

- The discussion-making process is introduced by the interpretative matrix by 
interpreting the relationship among links connecting the pair of elements.

- It is obtained when the ISM methodology is combined with the interpretative matrix.

- It gives answers to "why" also in theory building which is not possible in ISM.

After developing TISM based model, MICMAC analysis has been done to develop a graph-based on driving power and dependence power.

\section{Result and Analysis}

Empirical Analysis has been conducted using one of the methodology EFA discussed earlier. Later on, another methodology named TISM has been employed on the results of EFA. After that MICMAC technique has been employed to get the defined objectives.

A. Empirical Analysis

In this analysis, EFA is used to get hidden constructs. For this, 3 tests are conducted.

- Reliability test is performed for each hidden construct to get Cronbach's alpha (Gudmundsson, 2004).

- Keyser- Mayer-Olkin (KMO) test is done to check the accuracy of sampling.

- Bartlett's test of sphericity for checking the correlation matrix whether it is an identity matrix or not.

Data reliability test has been performed for 20 barriers of all the 205 samples and values of Cronbach's alpha have been checked using reliability analysis through SPSS 23. The standard admissible range for reliability test should be as follows:

Excellent $-\geqslant 0.9$

Good - $\geqslant 0.8$

Unacceptable - > 0.5

Acceptable $-\geqslant 0.7$

Questionable - $\geqslant 0.6$

Poor - $\geqslant 0.5$

In this work, Cronbach's alpha value is 0.810 , which is in the range of 'Good' and 'Acceptable' (Field, 2009) which showed that there is internal consistency.

KMO measures are used for sample adequacy, and a higher value of KMO shows the suitability of EFA (Tan and Wisner, 2003). The obtained KMO has 0.743, which indicates that the pattern of correlations is relatively compact \& so factor analysis should yield distinct \& reliable factors. As the KMO value is greater than 0.7, it falls in the range of being good (Field, 2009). And since the value of Bartlett's test is less than 0.05, it may be considered to be significant i.e., there is some relationship between the variables that can be included during analysis. Cronbach's alpha value is used to examine reliability. For the data set to be reliable and acceptable, Cronbach's alpha is recommended to be higher than 0.6 (Lee et al., 
2012). Observing Table 2, it is quite clear that 4 items have factor loading less than 0.5 , so these 4 items are to be eliminated in the first iteration. Further, the model is run again, and Table 3 is obtained which shows that no more iterations are required, since the remaining 16 items have higher communality value \& factor loading greater than 0.5. Observing Table 3, we can see that all constructs have Cronbach's alpha higher than 0.7 and have an indication of having acceptable reliability for all constructs.

Table 2: Results of EFA for 20 Barriers

\begin{tabular}{|c|c|c|c|c|c|c|}
\hline $\begin{array}{l}\text { S. } \\
\text { no }\end{array}$ & Barriers & $\begin{array}{l}\text { Factor } \\
\text { loading }\end{array}$ & $\begin{array}{c}\text { Extracted } \\
\text { communality }\end{array}$ & $\begin{array}{l}\text { Cronbach's } \\
\text { alpha }\end{array}$ & Eigenvalue & $\begin{array}{c}\text { Cumulative } \\
\text { percentage of } \\
\text { variance explained }\end{array}$ \\
\hline 1 & B16 & 0.954 & 0.934 & \multirow{6}{*}{0.972} & \multirow{6}{*}{5.294} & \multirow{6}{*}{26.468} \\
\hline 2 & B15 & 0.95 & 0.925 & & & \\
\hline 3 & B3 & 0.943 & 0.897 & & & \\
\hline 4 & B12 & 0.932 & 0.873 & & & \\
\hline 5 & B13 & 0.907 & 0.827 & & & \\
\hline 6 & B9 & 0.9 & 0.834 & & & \\
\hline 7 & B6 & 0.912 & 0.844 & \multirow{6}{*}{0.896} & \multirow{6}{*}{4.042} & \multirow{6}{*}{46.677} \\
\hline 8 & B8 & 0.908 & 0.844 & & & \\
\hline 9 & B11 & 0.884 & 0.804 & & & \\
\hline 10 & B7 & 0.856 & 0.762 & & & \\
\hline 11 & B14 & 0.826 & 0.717 & & & \\
\hline 12 & B17 & 0.307 & 0.173 & & & \\
\hline 13 & $\mathrm{~B} 1$ & 0.968 & 0.949 & \multirow{4}{*}{0.84} & \multirow{4}{*}{2.906} & \multirow{4}{*}{61.206} \\
\hline 14 & $\mathrm{~B} 2$ & 0.957 & 0.933 & & & \\
\hline 15 & B4 & 0.939 & 0.907 & & & \\
\hline 16 & B18 & 0.315 & 0.238 & & & \\
\hline 17 & $\mathrm{~B} 10$ & 0.922 & 0.859 & \multirow{4}{*}{0.671} & \multirow{4}{*}{2.188} & \multirow{4}{*}{72.144} \\
\hline 18 & B5 & 0.913 & 0.843 & & & \\
\hline 19 & B19 & 0.374 & 0.161 & & & \\
\hline 20 & B20 & 0.308 & 0.106 & & & \\
\hline
\end{tabular}

Table 3: Results of EFA for 16 Barriers

\begin{tabular}{|c|c|c|c|c|c|c|c|}
\hline $\begin{array}{l}\text { S. } \\
\text { no }\end{array}$ & Barriers & $\begin{array}{l}\text { Factor } \\
\text { loading }\end{array}$ & $\begin{array}{c}\text { Extracted } \\
\text { communality }\end{array}$ & $\begin{array}{c}\text { Cronbach's } \\
\text { alpha }\end{array}$ & $\begin{array}{l}\text { Eigen } \\
\text { value }\end{array}$ & $\begin{array}{c}\text { Cumulative } \\
\text { percentage of } \\
\text { variance } \\
\text { explained }\end{array}$ & $\begin{array}{l}\text { Construct } \\
\text { labelling }\end{array}$ \\
\hline 1 & B16 & 0.958 & 0.938 & \multirow{3}{*}{0.972} & \multirow{3}{*}{5.269} & \multirow{3}{*}{32.933} & \multirow{3}{*}{$\begin{array}{c}\text { Strategic } \\
\text { level barriers }\end{array}$} \\
\hline 2 & B15 & 0.95 & 0.923 & & & & \\
\hline 3 & B3 & 0.942 & 0.895 & & & & \\
\hline
\end{tabular}




\begin{tabular}{|c|c|c|c|c|c|c|c|}
\hline 4 & B12 & 0.931 & 0.872 & & & & \\
\hline 5 & B13 & 0.904 & 0.828 & & & & \\
\hline 6 & B9 & 0.905 & 0.842 & & & & \\
\hline 7 & B6 & 0.918 & 0.852 & \multirow{5}{*}{0.932} & \multirow{5}{*}{3.955} & \multirow{5}{*}{57.655} & \multirow{5}{*}{$\begin{array}{c}\text { Tactical } \\
\text { level barriers }\end{array}$} \\
\hline 8 & B8 & 0.917 & 0.859 & & & & \\
\hline 9 & B11 & 0.89 & 0.819 & & & & \\
\hline 10 & B7 & 0.86 & 0.769 & & & & \\
\hline 11 & B14 & 0.826 & 0.718 & & & & \\
\hline 12 & B1 & 0.974 & 0.959 & \multirow{3}{*}{0.966} & \multirow{3}{*}{2.829} & \multirow{3}{*}{75.337} & \multirow{3}{*}{$\begin{array}{l}\text { Operational } \\
\text { level barriers }\end{array}$} \\
\hline 13 & B2 & 0.962 & 0.94 & & & & \\
\hline 14 & B4 & 0.951 & 0.922 & & & & \\
\hline 15 & B10 & 0.979 & 0.966 & \multirow{2}{*}{0.98} & \multirow{2}{*}{2.017} & \multirow{2}{*}{87.944} & \multirow{2}{*}{$\begin{array}{l}\text { Performance } \\
\text { level barriers }\end{array}$} \\
\hline 16 & B5 & 0.98 & 0.97 & & & & \\
\hline
\end{tabular}

Generally, acceptance criteria for factor extraction are considered as eigenvalue is greater than and equal to one (Matook et al., 2009; Shankar et al., 2019, 2018). In this way, 4 constructs are eliminated and shown in Table 3. The fourth column of Table 3 shows that 16 remaining items have communality values higher than 0.5 and so, it shows that these remaining barriers are well reflected by the eliminated construct. Therefore, the results are acceptable and considered as respectable (Hou et al., 2014). Hence, the results of EFA validate the suggested 4 level structure for barriers of EVsCI \& hence these extracted constructs are levelled as Strategic, Tactical, Operational \& Performance as in Table 3.

\section{B.Results of TISM}

In order to establish an inter-relationship among the 16 barriers which are outcomes of EFA, recommended 9-stage TISM methodology is employed (Table 3). Different stages of this methodology (Jena et al., 2017) are listed below:-

Stage I: Identification of factors

After employing EFA methodology (Table 3), 16 potential barriers for shifting from traditional transportation systems to EVs are examined here for modeling.

Stage II: Determination of the contextual relationship

The contextual relationship between different barriers is described as Barrier 2 (B2) which will affect Barrier 3 (B3).

Stage III: Interpretation of relationship

Experts' observations are required to display whether B2 will affect B3 or not. If its contextual relationship exhibits "Yes", it is to be explained in what way B2 will affect B3.

Stage IV: Interpretive logic-knowledge base for pair-wise comparison.

To establish the pair-wise comparison for 16 barriers, an "Interpretive logicknowledge base" has been prepared. Experts' opinions are shown by the symbol 
"Y" and "N" for Yes and No respectively, and if "Y", the way will be explained in which it will affect other barriers.

Stage V: Reachability matrix and transitivity test

The opening reachability matrix has been developed from the interpretative logicknowledge base. One or zero is entered in the reachability matrix by looking at the knowledge base values entry code. Here one or zero is entered in the reachability matrix if the entry code in the knowledge base is " $\mathrm{Y}$ " or " $\mathrm{N}$ " respectively. The transitivity rule is checked in order to reach from opening matrix to concluding matrix. If transitive links are found, the knowledge base is renewed as "Y" for the new link, and "transitive" is entered in the interpretation column. For a significant transitive link, its reason needs to be given with transitive entry. The final/concluding reachability matrix is given in Table 4. If B4 is related to B1and $\mathrm{B} 1$ relates to $\mathrm{B} 2$, it is established that $\mathrm{B} 4$ relates to $\mathrm{B} 2$. The transitive linkage between two barriers is denoted by $1^{\prime}$

Table 4: Final Rechability Matrix (With Transistivity)

\begin{tabular}{|c|c|c|c|c|c|c|c|c|c|c|c|c|c|c|c|c|c|}
\hline & B1 & B2 & B3 & B4 & B5 & B6 & B7 & B8 & B9 & B10 & B11 & B12 & B13 & B14 & B15 & B16 & $\begin{array}{c}\text { Driving } \\
\text { power }\end{array}$ \\
\hline B1 & 1 & 1 & 1 & 1 & 1 & $1^{\prime}$ & $1^{\prime}$ & 1 & $1^{\prime}$ & 1 & $1^{\prime}$ & $1^{\prime}$ & $1^{\prime}$ & 1 & 0 & 0 & 14 \\
\hline B2 & 1 & 1 & $1^{\prime}$ & $1^{\prime}$ & $1^{\prime}$ & 0 & $1^{\prime}$ & 1 & $1^{\prime}$ & $1^{\prime}$ & $1^{\prime}$ & 0 & $1^{\prime}$ & 1 & 0 & 0 & 12 \\
\hline B3 & 1 & 1 & 1 & $1^{\prime}$ & 1 & 1 & 1 & $1^{\prime}$ & $1^{\prime}$ & 1 & $1^{\prime}$ & 0 & 0 & $1^{\prime}$ & 0 & 0 & 12 \\
\hline B4 & 0 & 0 & 0 & 1 & $1^{\prime}$ & 1 & 1 & $1^{\prime}$ & 1 & $1^{\prime}$ & $1^{\prime}$ & 1 & 0 & $1^{\prime}$ & 0 & 0 & 10 \\
\hline B5 & 0 & 0 & 0 & 0 & 1 & 0 & 0 & 0 & 0 & 1 & 0 & 0 & 0 & 0 & 0 & 0 & 2 \\
\hline B6 & 0 & 0 & 0 & 0 & $1^{\prime}$ & 1 & 0 & 0 & 1 & $1^{\prime}$ & 1 & 0 & 0 & 0 & 0 & 0 & 5 \\
\hline B7 & 0 & 0 & 0 & 0 & 1 & 0 & 1 & 0 & $1^{\prime}$ & $1^{\prime}$ & 1 & 0 & $1^{\prime}$ & 1 & 0 & 0 & 7 \\
\hline $\mathrm{B} 8$ & 0 & 0 & 0 & 0 & $1^{\prime}$ & $1^{\prime}$ & $1^{\prime}$ & 1 & 1 & 1 & $1^{\prime}$ & 0 & 1 & 1 & 0 & 0 & 9 \\
\hline B9 & 0 & 0 & 0 & 0 & 1 & 1 & 0 & 0 & 1 & 1 & $1^{\prime}$ & 0 & 0 & 0 & 0 & 0 & 5 \\
\hline B10 & 0 & 0 & 0 & 0 & 1 & 0 & 0 & 0 & 0 & 1 & 0 & 0 & 0 & 0 & 0 & 0 & 2 \\
\hline B11 & 0 & 0 & 0 & 0 & 1 & $1^{\prime}$ & 0 & 0 & 1 & 1 & 1 & 0 & 0 & 0 & 0 & 0 & 5 \\
\hline B12 & 0 & 0 & 0 & 1 & 0 & $1^{\prime}$ & $1^{\prime}$ & 1 & $1^{\prime}$ & $1^{\prime}$ & 0 & 1 & $1^{\prime}$ & $1^{\prime}$ & 0 & 0 & 9 \\
\hline B13 & 0 & 0 & 0 & 0 & 1 & 0 & 1 & 0 & $1^{\prime}$ & 1 & 1 & 0 & 1 & $1^{\prime}$ & 0 & 0 & 7 \\
\hline B14 & 0 & 0 & 0 & 0 & $1^{\prime}$ & 0 & 1 & 0 & $1^{\prime}$ & $1^{\prime}$ & 1 & 0 & 1 & 1 & 0 & 0 & 7 \\
\hline B15 & 1 & 1 & 1 & 1 & $1^{\prime}$ & $1^{\prime}$ & $1^{\prime}$ & 1 & $1^{\prime}$ & $1^{\prime}$ & $1^{\prime}$ & 1 & $1^{\prime}$ & 1 & 1 & 1 & 16 \\
\hline B16 & 1 & 1 & 1 & 1 & 1 & $1^{\prime}$ & $1^{\prime}$ & 1 & 1 & 1 & 1 & 1 & 1 & 1 & 1 & 1 & 16 \\
\hline $\begin{array}{c}\text { Dep } \\
\text { end } \\
\text { enc } \\
\text { e }\end{array}$ & 5 & 5 & 5 & 7 & 15 & 10 & 11 & 8 & 14 & 16 & 13 & 5 & 9 & 11 & 2 & 2 & \\
\hline
\end{tabular}

Stage VI: Level partitions

To know the position of identified barriers, level partitioning is done (Jharkharia 
and Shankar, 2004; Ravi and Shankar, 2005). Table 5, shows the level partitioning of the concluding/final reachability matrix. Then diagraph and TISM model is developed with the help of identified barriers of charging infrastructure of EVs.

Stage VII: Develop digraph

In this step, a diagraph is to prepare for barriers. It is formed by placing all the barriers at their level as obtained in the previous step and direct link is drawn among barriers as per their relation in the concluding matrix.

Stage VIII: Interpretive matrix

A binary interaction matrix is obtained using the final digraph in which all ' 1 ' are shown. Further, a cell having ' 1 ' is interpreted with the help of proper interpretation. These interpretations are taken from the interpretive logic-knowledge base. This matrix is known as an interpretive matrix.

Stage IX: Total Interpretive Structural Model

Combining the Interpretive matrix and diagraph, a TISM model for barriers is prepared. In a diagraph nodes and links are shown. TISM model (Figure 2) gives a full analysis of nodes and links. Dotted lines represent significant transitive links and solid lines represent direct links.

Table 5: Partitioning of reachability matrix (iteration 1-7)

\begin{tabular}{|c|c|c|c|c|}
\hline $\begin{array}{c}\text { Barriers } \\
\text { code }\end{array}$ & Reachability set & Antecedent set & Intersection & Level \\
\hline B1 & $1,2,3$ & $1,2,3,15,16$ & $1,2,3$ & VIth \\
\hline B2 & $1,2,3$ & $1,2,3,15,16$ & $1,2,3$ & VIth \\
\hline B3 & $1,2,3$ & $1,2,3,15,16$ & $1,2,3$ & VIth \\
\hline B4 & 4,12 & $1,2,3,4,12,15,16$ & 4,12 & Vth \\
\hline B5 & 5,10 & $1,2,3,4,5,6,7,8,9,10,11,13,14,15,16$ & 5,10 & Ist \\
\hline B6 & $6,9,11$ & $1,3,4,6,8,9,11,12,15,16$ & $6,9,11$ & IInd \\
\hline B7 & $7,13,14$ & $1,2,3,4,7,8,12,13,14,15,16$ & $7,13,14$ & IIIrd \\
\hline B8 & 8 & $1,2,3,4,8,12,15,16$ & 8 & IVth \\
\hline B9 & $6,9,11$ & $1,2,3,4,6,7,8,9,11,12,13,14,15,16$ & $6,9,11$ & Ind \\
\hline B10 & 5,10 & $1,2,3,4,5,6,7,8,9,10,11,12,13,14,15,16$ & 5,10 & Ist \\
\hline B11 & $6,9,11$ & $1,2,3,4,6,7,8,9,11,13,14,15,16$ & $6,9,11$ & IInd \\
\hline B12 & 4,12 & $1,4,12,15,16$ & 4,12 & Vth \\
\hline B13 & $7,13,14$ & $1,2,7,8,12,13,14,15,16$ & $7,13,14$ & IIIrd \\
\hline B14 & $7,13,14$ & $1,2,3,4,7,8,12,13,14,15,16$ & $7,13,14$ & IIIrd \\
\hline B15 & 15,16 & 15,16 & 15,16 & VIIth \\
\hline B16 & 15,16 & 15,16 & 15,16 & VIIth \\
\hline
\end{tabular}

a) MICMAC

This analysis is used after the TISM result to analyze the dependence \& driving 
power of identified barriers (Ravi and Shankar, 2005). It selects the barriers, answerable to the entire framework. The sum of all "1" of the columns and rows (Table 4) will indicate the dependence \& driving power, respectively for each other barrier. All the selected barriers can be shown in 4 different quadrants by employing MICMAC analysis (Fig 3).

Quadrant 1: Autonomous Barriers:

The barriers of this quadrant have very low dependence as well as very low driving power.

Quadrant 2: Dependent Barriers:

The barriers of this quadrant will have very high dependence but very low driving power. 8 barriers such as B13, B7, B14, B6, B11, B9, B5, B10 are available in this quadrant.

Quadrant 3: Unstable \& leakage Barriers:

This quadrant may contain those barriers which have very high driving power as well as very high dependence. The barriers coming in this quadrant are considered unstable. If any action is taken on barriers coming in this quadrant, it will also influence other barriers. These barriers have a special feature known as the feedback effect. This feature has effect on themselves. Also, no barriers are available in this quadrant and it shows the steadiness of the model. 


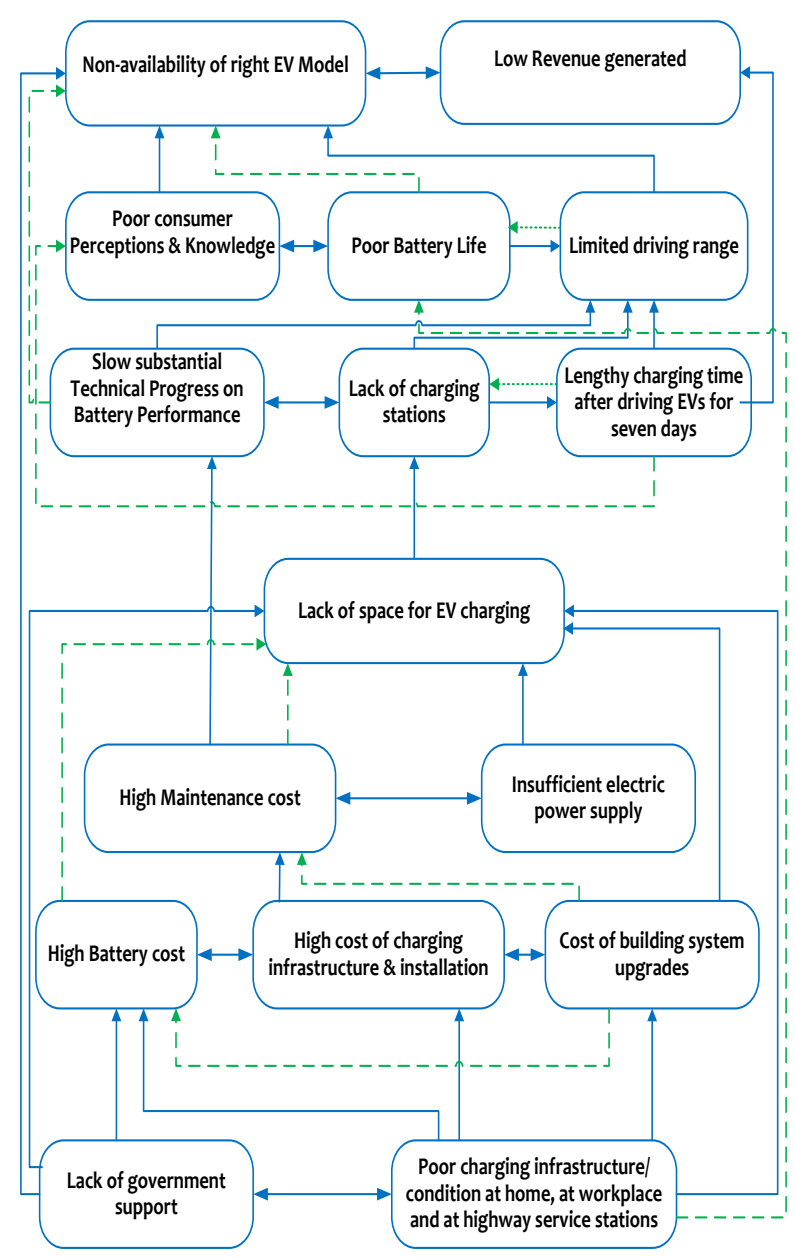

Fig. 2: TISM-based model

\section{Quadrant 4: Independent/Driving Barriers}

This quadrant has barriers of very high driving power and low dependence. Generally, very high driving power barriers are termed key barriers. So, these barriers are answerable for driving the full system. 8 barriers are lying in this quadrant such as B15, B16, B1, B2, B3, B12, B4, B8.

\section{Discussion and Implications}

This study presented 16 statistical barriers of EVsCI for the transition from a traditional transportation system to EVs transportation system.

This study also proposed a hierarchical advanced methodology known as TISM to facilitate industries as well as government/policymakers for adopting electric vehicles in transportation systems. MICMAC analysis (Fig-3) shows that, since the B16 has the highest driving power and lowest dependency, the stakeholder should not be more dependent on the system. Stakeholders should not take initiation 
without getting proper government support and policy. The results of the MICMAC analysis highlight the comparison and inter-relationship among barriers. To deal with various barriers, it is important to know the influence of each barrier in replacing traditional transportation systems with EVs. Barriers have been identified using a literature survey and experts' opinions. Significance and correlation among identified barriers are to be tested. EFA methodology has been used for these testing and its results have been analyzed and then reliability tests, as well as factor analysis, are done. The reliability coefficient/Cronbach's alpha $(\geqslant 0.7)$ is obtained which shows the reliability of the barriers. It also gives signal to proceed for further analysis. The KMO obtained is 0.743 which is acceptable as per recommendation. The result of Bartlett's test of Sphericity $(<0.05)$ shows the significance of results. Hidden constructs are also identified employing EFA methodology. 4 constructs were derived from the results of EFA and these are levelled as strategic, tactical, operational, and performance.

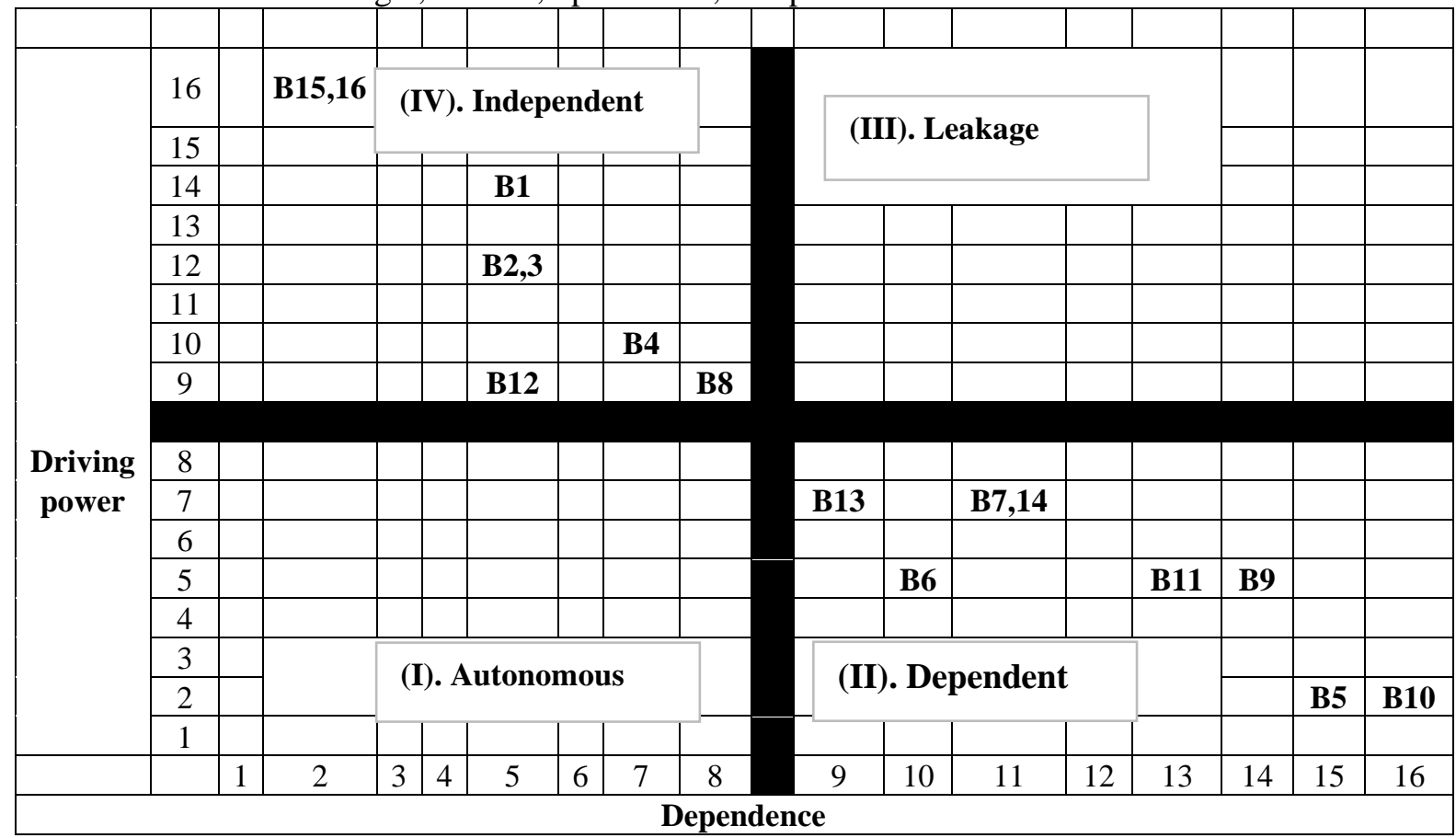

Fig. 3: MICMAC Analysis

Further,16 barriers have been identified and finalized. The next step is to get inter-relationship among barriers and establish priorities. If inter-relationship among barriers are not examined critically, their priority with respect to their contribution towards utilization may be affected. To get an inter-relationship among barriers, TISM has been employed. Next, MICMAC analysis was performed for these identified barriers. 
These barriers are categorized into 4 quadrants: -

- Autonomous

- Dependent

- Linkage

- Independent

The following observations have been summarised from MICMAC analysis.

- Not a single barrier came in quadrant 1 (autonomous variable). This implied that not a single barrier is disconnected/autonomous from the system

- As shown in Figure 3, out of 16 barriers, 8 barriers exist in quadrant 2 having poor driving power for rest barriers. At the same time, these are high dependence barriers as compared to other barriers. B7 and B14 are lying at the same place having a driving power of 7 and a dependence of 11 . B5 and B10 have the same driving power 2 and dependence 15 and 16 respectively. B5 \& B10 position themselves at the upper level of the TISM model. Barriers of quadrant 2 are highly dependent on the barriers of quadrant 4 . Therefore, the policymakers have to be more sensitive towards barriers of quadrant 4 . The barriers of quadrant 4 can drive rest barriers.

- The barriers coming in this quadrant 3 are considered unstable and will have very high driving power as well as dependence. The non-existence of any barriers in this section shows the steadiness of the entire model.

- The barriers falling in quadrant 4 (B15, B16, B1, B2, B3, B4, B8, B12) have very high driving power but very low dependence w.r.t other barriers, and hence it comes in the low levels of the TISM-based model. Lack of proper govt. support is a very important barrier, which requires proper attention by policymakers so that EVsCI be modified and modernized.

\section{Comparison of EFA and TISM Results}

Four distinct constructs for the 16 barriers namely Strategic, Tactical, Operational, and Performance (Table 3) have been provided by EFA. For the EFA, we have taken 205 sets of respondents using a questionnaire-based survey. The identified barriers using EFA methodology were modeled by taking 4 area experts, related to that field. A TISM model was prepared with the help of the opinions of experts. TISM methodology showed similarity with outcomes of EFA methodology although different approaches, respondents, and context were taken. Driving power and dependence among different barriers can be shown in the TISM model as it cannot be possible in EFA. B5 and B10 came at the upper level of the model and these barriers come in the quadrant of the dependent variable having the lowest driving power. EFA has also placed B5 and B10 to different construct known as performance level (Table 3). In the TISM model, B10 and B5 are driven by B9, B11, B13. B9 is driven by B6. B11 is driven by B7, B14, B13 (Fig 2). B10 and B5 assisted by the remaining barriers are shown in (Fig. 3). TISM shows driving power 
and dependence for these identified barriers. B16 and B15 have the strongest driving power with respect to all barriers under the strategic level of EFA.

\section{Conclusions and Scope of Future work}

This work uses transition management concept and stakeholder theory along with literature reviews, experts' opinions, and interviews with academicians, government officials, \& representatives of companies to identify 20 barriers. The stakeholders' views are considered in identifying these barriers. This proposed framework is helpful in understanding stakeholder's roles and how they can be helpful for other stakeholders. An attempt has also been made to reduce the emission of $\mathrm{CO}_{2}$ in the transportation system and transform it into smart transportation. In this work, a four-level framework has been employed and barriers for not adopting EVs in place of the traditional transportation system have been identified. A very important purpose of this research work is to identify hidden constructs for barriers. By employing EFA and analyzing results, 4 hidden constructs are obtained, such as strategic, tactical, operational, and performance \& a 4-level transition management has been validated. Furthermore, this work also develops a hierarchy of these barriers to get inter-relationship among these barriers. TISM methodology gives a model and interpretation of links and nodes can be done in a diagraph. After that, the identified 16 barriers are grouped in 4 quadrants employing MICMAC analysis. Then analysis has been done to differentiate among driving barriers which have strong effect on some other barriers and dependent barriers which are strongly affected by other barriers. TISM model and MICMAC analysis show strategic barriers which have strong driving power. It is necessary and important to emphasize more on higher factor loading strategic barriers such as B15, B1, B2, B4. These barriers will have high driving influence on the operational level barriers. So, proper attention should be given by policymakers to strategic level barriers to achieve sustainability in the adoption of EVs in place of the traditional transportation system.

In this work, unified EFA-TISM access has been proposed to identify strategically important barriers of EVsCI through transition management work and to develop 7 levels of a hierarchical model for these barriers. TISM model shows inter-relationship among these barriers. This work also points out the need of minimizing drawbacks/demerits in the path of providing good infrastructure/space for charging EVs.

More barriers may be identified to prepare such other models. Further, the analysis can be done using Structural Equation Modeling (SEM). 


\section{References}

Allen, M. R. et al. (2009). Warming caused by cumulative carbon emissions towards the trillionth tonne, Nature. Nature Publishing Group, 458(7242), 1163 1166.

Bradley, T. H. and Frank, A. A. (2009). Design, demonstrations and sustainability impact assessments for plug-in hybrid electric vehicle. Renewable and Sustainable Energy Reviews, 13(1), 115 - 128.

Browne, D., O' Mahony, M. and Caulfield, B. (2012). How should barriers to alternative fuels and vehicles be classified and potential policies to promote innovative technologies be evaluated? Journal of Cleaner Production, 35, 140 151 .

Brownstone, D., Bunch, D. S. and Train, K. (2000). Joint mixed logit models of stated and revealed preferences for alternative-fuel vehicles. Transportation Research Part B:Methodological, 34, 315 - 338.

Bubeck, S., Tomaschek, J. and Fahl, U. (2016). Perspectives of electric mobility: Total cost of ownership of electric vehicles in Germany. Transport Policy, 50, 63 77.

Chen, Y., Ardila-Gomez, A. and Frame, G. (2017). Achieving energy savings by intelligent transportation systems investments in the context of smart cities. Transportation Research Part D: Transport and Environment, 54, 381 - 396.

Choon Tan, K., \& Wisner, J. D. (2003). A study of operations management constructs and their relationships. International Journal of Operations \& Production Management, 23(11), 1300-1325.

Din, S., Paul, A. and Rehman, A. (2019). 5G-enabled Hierarchical architecture for software-defined intelligent transportation system. Computer Networks, 150, 81-89.

Dua, R. White, K. and Lindland, R. (2019). Understanding potential for battery electric vehicle adoption using large-scale consumer profile data. Energy Policy, 5, $515-524$.

Dubey, R. et al. (2017) Sustainable supply chain management: framework and further research directions. Journal of Cleaner Production, 1119 - 1130. 
Egbue, O. and Long, S. (2012). Barriers to widespread adoption of electric vehicles: An analysis of consumer attitudes and perceptions. Energy Policy, 48(June), 717 729 .

Ehsani, M., Gao, Y. and Emadi, A. (2010). Modern Electric, Hybrid Electric, and Fuel Cell Vehicles, Modern Electric. Hybrid Electric, and Fuel Cell Vehicles, (CRC Press,New York), 2020.

Fabrigar, L. R., Wegener, D. T., MacCallum, R. C., \& Strahan, E. J. (1999). Evaluating the use of exploratory factor analysis in psychological research. Psychological Methods, 4(3), 272 - 299.

Field, A. (2009). Discovering Statistics using IBM SPSS Statistics - Cluster Analysis, Discovering Statistics using IBM SPSS Statistics, 58, 297 - 321.

Floyd, F. J., \& Widaman, K. F. (1995). Factor analysis in the development and refinement of clinical assessment instruments. Psychological Assessment, 7(3), 286299.

Graham-Rowe, E. et al. (2012). Mainstream consumers driving plug-in batteryelectric and plug-in hybrid electric cars: A qualitative analysis of responses and evaluations, Transportation Research Part A: Policy and Practice. Elsevier Ltd, $46(1), 140-153$.

Grote, M. et al. (2019). Locating residential on-street electric vehicle charging infrastructure: A practical methodology, Transportation Research Part D: Transport and Environment, $15-27$.

Gudmundsson, S. V. (2004). Management emphasis and performance in the airline industry: An exploratory multilevel analysis, Transportation Research Part E: Logistics and Transportation Review, 40(6), 443 - 463.

Hair, J. F., Black, W. C., Babin, B. J., \& Anderson, R. E. (2010). Multivariate data analysis (Seven ed.). Upper Saddle River, NJ Prentice Hall: Pearson.

Hou, D. et al. (2014). Factor analysis and structural equation modelling of sustainable behaviour in contaminated land remediation. Journal of Cleaner Production, 439 - 449.

IEA (2015). $\mathrm{CO}_{2}$ Emissions from Fuel Combustion 2005, $\mathrm{CO}_{2}$ Emissions from Fuel Combustion 2005. 
Jena, J. et al. (2016). A TISM modeling of critical success factors of smartphone manufacturing ecosystem in India. Journal of Advances in Management Research, $13(2), 203-224$.

Jena, J. et al. (2017). Total Interpretive Structural Modeling (TISM): approach and application. Journal of Advances in Management Research, 14(2), 162 - 181.

Jharkharia, S. and Shankar, R. (2004). IT enablement of supply chains: modeling the enablers. International Journal of Productivity and Performance Management, 53(8),700 - 712 .

Jinyong Shin, Jaesin Oh, Dae-Yul Jaeong (2020). An Empirical Study on the Social Marketing of Companies in India. Journal of System and Management Sciences, 10(4), 86-101.

Kannan, D. (2018). Role of multiple stakeholders and the critical success factor theory for the sustainable supplier selection process. International Journal of Production Economics. Elsevier Ltd, 195, 391 - 418.

Kemp, R., Loorbach, D. and Rotmans, J. (2007). Transition management as a model for managing processes of co-evolution towards sustainable development. International Journal of Sustainable Development and World Ecology, 14(1), 78 91.

Krause, R. M. et al. (2013). Perception and reality: Public knowledge of plug-in electric vehicles in 21 U.S. cities, Energy Policy, 433 - 440.

Lane, B. and Potter, S. (2007). The adoption of cleaner vehicles in the UK: exploring the consumer attitude-action gap. Journal of Cleaner Production, 15(11 - 12), $1085-1092$.

Larson, P. D. et al. (2014). Consumer attitudes about electric cars: Pricing analysis and policy implications, Transportation Research Part A: Policy and Practice. Elsevier Ltd, 69(September), 299 - 314.

Lee, A. H. I., Wang, W. M. and Lin, T. Y. (2010). An evaluation framework for technology transfer of new equipment in high technology industry, Technological Forecasting and Social Change, 135 - 150.

Lee, J. H., Kim, H. il and Phaal, R. (2012). An analysis of factors improving 
technology roadmap credibility: A communications theory assessment of roadmapping processes, Technological Forecasting and Social Change, 263 - 280.

Li, C., Ren, J. and Wang, H. (2016). A system dynamics simulation model of chemical supply chain transportation risk management systems, Computers and Chemical Engineering. Elsevier Ltd, 89, 71 - 83.

Loorbach, D., Van Der Brugge, R. and Taanman, M. (2008). Governance in the energy transition: Practice of transition management in the Netherlands. International Journal of Environmental Technology and Management, 9(2 - 3), 294 -315 .

Lopez-Behar, D. et al. (2019). Putting electric vehicles on the map: A policy agenda for residential charging infrastructure in Canada. Energy Research and Social Science, $29-37$.

Mandal, A. and Deshmukh, S. G. (1994). Vendor Selection Using Interpretive Structural Modelling ( ISM ), International Journal, 14(6), 52 - 59.

Matook, S., Lasch, R. and Tamaschke, R. (2009). Supplier development with benchmarking as part of a comprehensive supplier risk management framework. International Journal of Operations and Production Management, 29(3), 241 - 267.

Matthews, H. D. et al. (2009). The proportionality of global warming to cumulative carbon emission. Nature, 459(7248), $829-832$.

Meinshausen, M. et al. (2009). Greenhouse-gas emission targets for limiting global warming to $2^{\circ}$ C, Nature. Nature Publishing Group, 458(7242), 1158 - 1162.

Mosca, A., Vidyarthi, N. and Satir, A. (2019). Integrated transportation inventory models: A review, Operations Research Perspectives, 6(September 2018), $100-101$.

Nicholas Stern (2006). Stern review on the economics of climate change:stern review on the economics change, Uk Treasury.

Nocera, S. and Cavallaro, F. (2016). The competitiveness of alternative transport fuels for $\mathrm{CO}_{2}$ emissions, Transport Policy. Elsevier, 50, 1 - 14 .

Noel, L. et al. (2019). Navigating expert skepticism and consumer distrust: 
Rethinking the barriers to vehicle-to-grid (V2G) in the Nordic region. Transport Policy, 76, $67-77$.

O' Neill, E. et al. (2019). Barriers to electric vehicle uptake in Ireland: Perspectives of car-dealers and policy-makers. Case Studies on Transport Policy, $118-127$.

Petrov, T., Dado, M. and Ambrosch, K. E. (2017). Computer Modelling of Cooperative Intelligent Transportation Systems, Procedia Engineering. The Author(s), 192, $683-688$.

Potoglou, D. and Kanaroglou, P. S. (2007). Household demand and willingness to pay for clean vehicles, Transportation Research Part D:

Pradip Kumar Sarkar and Jain, A. K. (2018). Intelligent Transport System, PHI learning, 440.

Prud' homme, R. and Koning, M. (2012). Electric vehicles: A tentative economic and environmental evaluation. Transport Policy, 23, 60 - 69.

Rajput, S. and Singh, S. P. (2019). Identifying Industry 4.0 IoT enablers by integrated PCA-ISM-DEMATEL approach. Management Decision, 57(8), 1784 1817.

Ratanavaraha, V. and Jomnonkwao, S. (2015). Trends in Thailand $\mathrm{CO}_{2}$ emissions in the transportation sector and Policy Mitigation. Transport Policy. Elsevier, 41, 136 $-146$.

Ravi, V. and Shankar, R. (2005). Analysis of interactions among the barriers of reverse logistics, Technological Forecasting and Social Change, 72(8), 1011 - 1029.

Rezvani, Z., Jansson, J. and Bodin, J. (2015). Advances in consumer electric vehicle adoption research: A review and research agenda, Transportation Research Part D: Transport and Environment, 34, 122 - 136.

Robinson, J. et al. (2014). Business models for solar powered charging stations to develop infrastructure for electric vehicles, Sustainability, 6(10), 7358 - 7387.

Sadiku, M. N. O., Shadare, A. E. and Musa, S. M. (2017). Smart Transportation: A Primer. International Journal of Advanced Research in Computer Science and 
Software Engineering, 7(3), 6 - 7 .

Seung-Wan Ju, Lee-Sang Jung (2020). Experience Satisfaction and Buying intention of Exhibition Experience: An Empirical Study. Journal of System and Management Sciences, vol. 10, No. 1, 72-82

Shankar, R., Gupta, R. and Pathak, D. K. (2018). Modeling critical success factors of traceability for food logistics system, Transportation Research Part E: Logistics and Transportation Review, 119, 205 - 222.

Shankar, R., Pathak, D. K. and Choudhary, D. (2019). Decarbonizing freight transportation: An integrated EFA-TISM approach to model enablers of dedicated freight corridors, Technological Forecasting and Social Change. Elsevier, 143, pp. 85 - 100. doi: 10.1016/j.techfore.2019.03.010.

She, Z.-Y. et al. (2017). What are the barriers to widespread adoption of battery electric vehicles? A survey of public perception in Tianjin,China. Transport Policy, $56,29-40$.

Sierzchula, W. et al. (2014). The influence of financial incentives and other socioeconomic factors on electric vehicle adoption. Energy Policy, 68, 183 - 194.

Singh, M. D. et al. (2003). An interpretive structural modeling of knowledge management in engineering industries. Journal of Advances in Management Research, 1(1), $28-40$.

Siuhi, S. and Mwakalonge, J. (2016). Opportunities and challenges of smart mobile applications in transportation. Journal of Traffic and Transportation Engineering (English Edition). Elsevier Ltd, 3(6), 582 - 592.

Steinhilber, S., Wells, P. and Thankappan, S. (2013). Socio-technical inertia: Understanding the barriers to electric vehicles, Energy Policy, 60, 531 - 539.

Sushil (2012). Interpreting the Interpretive Structural Model. Global Journal of Flexible Systems Management, 13(2), 87 - 106.

Tabachnick, B. G., \& Fidell, L. S. (2007). Using Multivariate Statistics (5th ed.). New York: Allyn and Bacon.

Tachizawa, E. M., Alvarez-Gil, M. J. and Montes-Sancho, M. J. (2015). How 
"smart cities" will change supply chain management. Supply Chain Management, $20(3), 237-248$.

Tran, M. et al. (2013). Simulating early adoption of alternative fuel vehicles for sustainability, Technological Forecasting and Social Change. Elsevier Inc., 80(5), $865-875$.

Wang, Y. et al. (2018). Green information, green certification and consumer perceptions of remanufctured automobile parts, Resources, Conservation and Recycling. Elsevier B.V., 128, 187 - 196.

Warfield, J. N. (1974). Developing Subsystem Matrices in Structural Modeling, IEEE Transactions on Systems, Man and Cybernetics, SMC-4(1), 74 - 80.

Watson, R. H. (1978). Interpretive structural modeling-A Useful Tool for Technology Assessment? Technological Forecasting and Social Change. 11(2), $165-185$.

Yuen, K. F. et al. (2017). Antecedents and outcomes of sustainable shipping practices: The integration of stakeholder and behavioural theories, Transportation Research Part E: Logistics and Transportation Review. Elsevier, 108, 18 - 35.

Zhang, S. et al. (2018). Fine-grained vehicle emission management using intelligent transportation system data. Environmental Pollution, 241, 1027 - 1037.

Zheng, J. et al. (2012). Strategic policies and demonstration program of electric vehicle in China. Transport Policy, 19(1), $17-25$. 